\title{
Article
}

\section{Oil Spill Governance: Evidence from Bintan Island, Indonesia}

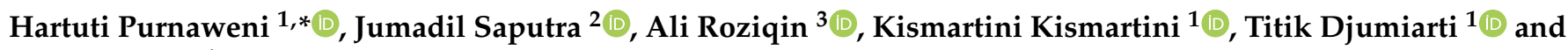 \\ Thomas Seitz ${ }^{4}$
}

check for updates

Citation: Purnaweni, H.; Saputra, J.; Roziqin, A.; Kismartini, K.; Djumiarti, T.; Seitz, T. Oil Spill Governance: Evidence from Bintan Island, Indonesia. Sustainability 2022, 14, 1603. https://doi.org/10.3390/ su14031603

Academic Editor: Tim Gray

Received: 7 December 2021

Accepted: 26 January 2022

Published: 29 January 2022

Publisher's Note: MDPI stays neutral with regard to jurisdictional claims in published maps and institutional affiliations.

Copyright: (C) 2022 by the authors. Licensee MDPI, Basel, Switzerland. This article is an open access article distributed under the terms and conditions of the Creative Commons Attribution (CC BY) license (https:// creativecommons.org/licenses/by/ $4.0 /)$.
1 Department of Public Administration, Universitas Diponegoro, Semarang 50275, Indonesia; kis_martini@yahoo.co.id (K.K.); titi_artik@yahoo.co.id (T.D.)

2 Faculty of Business, Economics and Social Development, Universiti Malaysia Terengganu, Kuala Nerus 21030, Malaysia; jumadil.saputra@umt.edu.my

3 Department of Government Studies, Universitas Muhammadiyah Malang, Malang 65144, Indonesia; aliroziqin@umm.ac.id

4 School of Politics, Public Affairs \& International Studies, University of Wyoming, 1000 E University Ave, Laramie, WY 82071, USA; tseitz@uwyo.edu

* Correspondence: hartutipurnaweni@gmail.com

\begin{abstract}
Issues of oil spills in various locations worldwide have been widely published in several studies. However, studies on policy management and strategies for handling cases related to oil spills are still limited. As one of the largest oil-producing countries with international shipping traffic, Indonesia is vulnerable to oil spills. Therefore, by drawing upon evidence from Bintan Island, this study aims to provide recommendations for stakeholders concerning governance and policy to address the oil spill case, which has had adverse social, economic, and environmental impacts. Data were collected from semi-structured interviews, focus group discussion, observation, actual online news, and official government reports using a case study approach. The result indicates that the local government is slow in responding to Bintan Island's reoccurring yearly oil spillage. Policy responses are still focused on repressive and conventional methods. Hence, preventive and multi-stakeholder governance is required to handle oil spills. Furthermore, this study provides an overview of the oil spill problem and its management strategy in developing countries, especially Indonesia.
\end{abstract}

Keywords: oil spill; impact; governance; sustainable; policy; stakeholder; tourism; fisherman

\section{Introduction}

Oil is a natural product often used to meet industrial, transportation, and household needs. However, only certain inland and outland sea areas are fortunate to have oil as a mining material. For the most part, the oil industry explores this natural product in the high seas waters [1], where its trade flows are transported by tankers [2]. This situation impacts increasing the potential for oil spills in the sea [3-5]. According to the UNCTAD (United Nations Conference on Trade and Development) [6], transporting crude oil and petroleum products by sea reached 59.503 billion ton-miles in 2019. This sometimes leads to oil spills capable of polluting the sea and damaging the environment.

Sulistyono [7], Assilzadeh and Gao [8], and Ismila Che Ishak et al. [2] stated that leading causes of oil spillage due to several human activities include shipping process, offshore oil drilling, oil spill accidents from tankers, and leaks of offshore oil rigs. Oil and water are two immiscible substances, therefore, when they meet in the same activity area, they cause problems.

Although the oil industry plays a strategic role in the economies of most developing countries [9], they also experience problems associated with spillage [9-12]. Intense industrial activity in the high seas, such as oil drilling, can damage the environment enormously, categorised as negative externalities [9]. Brekke and Solberg [13] stated that $48 \%$ of oil spilled into the sea is fuel, and this condition certainly has the potential to cause damage to the marine ecosystem. According to Al-Majed et al. [1], the impact of oil spills in the 
sea is hazardous for socio-economic life and marine ecosystems. Therefore, a rapid response policy by the authorities to clean up oil spills needs to be implemented to minimize environmental pollution and damage [11,14].

Indonesia is one of the largest oil and gas producing countries with international shipping traffic areas [15]. Several cases of oil spills have occurred in numerous parts of the country, as shown in Table 1.

Table 1. Several Cases of Oil Spill in Indonesia.

\begin{tabular}{|c|c|c|c|c|}
\hline No & Year & Location & Case & References \\
\hline 1 & 1975 & Malacca Strait & $\begin{array}{l}\text { Shipwreck of the Shown Maru tanker, which } \\
\text { spilled } 1 \text { million barrels of diesel oil }\end{array}$ & Robertua \& Karyoprawiro [16] \\
\hline 2 & February 1979 & $\begin{array}{l}\text { Lhokseumawe } \\
\text { Harbor }\end{array}$ & $\begin{array}{c}\text { Leak of the Golden Win tanker carrying } 1500 \mathrm{KL} \\
\text { of kerosene }\end{array}$ & Masdin [17] \\
\hline 3 & $\begin{array}{l}\text { December } \\
1979\end{array}$ & $\begin{array}{l}\text { Buleleng Bali } \\
\text { Harbor }\end{array}$ & $\begin{array}{l}\text { Choya Maru tanker crash in December spilled } \\
\qquad 300 \text { tons of gasoline }\end{array}$ & \\
\hline 4 & January 1993 & Malacca Strait & $\begin{array}{l}\text { Shipwreck of the Maersk Navigator Tank, } \\
290,000 \text { tons }\end{array}$ & AP News [18] \\
\hline 5 & 1996 & Natuna & $\begin{array}{l}\text { Sinking of KM Hatamas II, which contains MFO, } \\
\qquad 4000 \text { tons }\end{array}$ & \\
\hline 6 & October 1997 & Singapore Strait & $\begin{array}{l}\text { Orapin Global ship collides with the tanker } \\
\text { Evoikos, 28,500 tons }\end{array}$ & Kareem [19] \\
\hline 7 & April 2000 & Cilacap & $\begin{array}{l}\text { Leak of the Pertamina Cilacap (King Fisher) } \\
\text { pipeline caused } 600,000 \text { barrels of crude oil to } \\
\text { spill into the sea }\end{array}$ & Wibowo [20] \\
\hline 8 & July 2003 & Palembang & $\begin{array}{c}\text { Collision between the PLTU-1/PLN barge } \\
\text { carrying } 363 \mathrm{KL} \text { IDF with the cargo ship An } \\
\text { Giang caused the pollution of the Musi river } \\
\text { around Palembang }\end{array}$ & Liputan 6 [21] \\
\hline 9 & $2003 \& 2004$ & $\begin{array}{l}\text { Kepualauan } \\
\text { Seribu, Jakarta }\end{array}$ & Oil pipelines and oil tankers, 984 tons & Suhery, Damar \& Effendi [22] \\
\hline 10 & October 2004 & $\begin{array}{l}\text { Karangsong } \\
\text { Beach, Indramayu }\end{array}$ & $\begin{array}{l}\text { The spill of crude oil from Pertamina UP VII } \\
\text { Balongan. This spill damaged the coral reefs } \\
\text { where the surrounding community nurtures fish }\end{array}$ & $\begin{array}{c}\text { Yanti [15]; Sinurat, Ismanto \& } \\
\text { Hariyadi [23]; Feti, Hadi \& } \\
\text { Purnaweni [24]; } \\
\text { Sugihamretha [25] }\end{array}$ \\
\hline 11 & August 2009 & $\begin{array}{l}\text { Montara Case } \\
\text { (75 days) }\end{array}$ & $\begin{array}{l}400 \text { barrels / day, from the explosion of an oil rig } \\
\text { off the coast of northwestern Australia that flows } \\
\text { into the Timor Sea, and pollutes the Indonesian } \\
\text { coast, } 5000-10,000 \text { barrels / day }\end{array}$ & $\begin{array}{l}\text { Panjaitan, Novianti \& } \\
\text { Farisi [26] }\end{array}$ \\
\hline 12 & 2015 & $\begin{array}{l}\text { Central } \\
\text { Kalimantan }\end{array}$ & $\begin{array}{c}\text { Ship collision between MT Alyarmouk and MT } \\
\text { Sinar Kapuas. } 4500 \text { MT crude oil spilled into } \\
\text { the sea }\end{array}$ & Reuters [27] \\
\hline 13 & 2017 & Palembang & $\begin{array}{l}\text { Wan Hai } 301 \text { Tanker Motor (MT) collided with the } \\
\text { Denver MT APL. } 300 \text { tons of oil spilled in the sea }\end{array}$ & Winarto [28] \\
\hline 14 & March 2018 & Balikpapan & $\begin{array}{c}200,700 \mathrm{~m}^{3} \text { or } 1.3 \text { million barrels of oil spilled in } \\
\text { the sea }\end{array}$ & $\begin{array}{l}\text { Ahyadi, Syarifudin, } \\
\text { Khairunnisa, Ximenes, \& } \\
\text { Hamdi [29] }\end{array}$ \\
\hline 15 & August 2019 & $\begin{array}{l}\text { Montara, Nusa } \\
\text { Tenggara Timur }\end{array}$ & 30 thousand barrels of spilled oil & Nurdiana [30] \\
\hline
\end{tabular}

Table 1 shows that various oil spill events in Indonesia occurred on a large scale. However, these findings do not indicate that stakeholders can rule out smaller oil spills such as those in the waters of the Bintan Island, Riau Province (Figure 1), which is the locus in this study. 


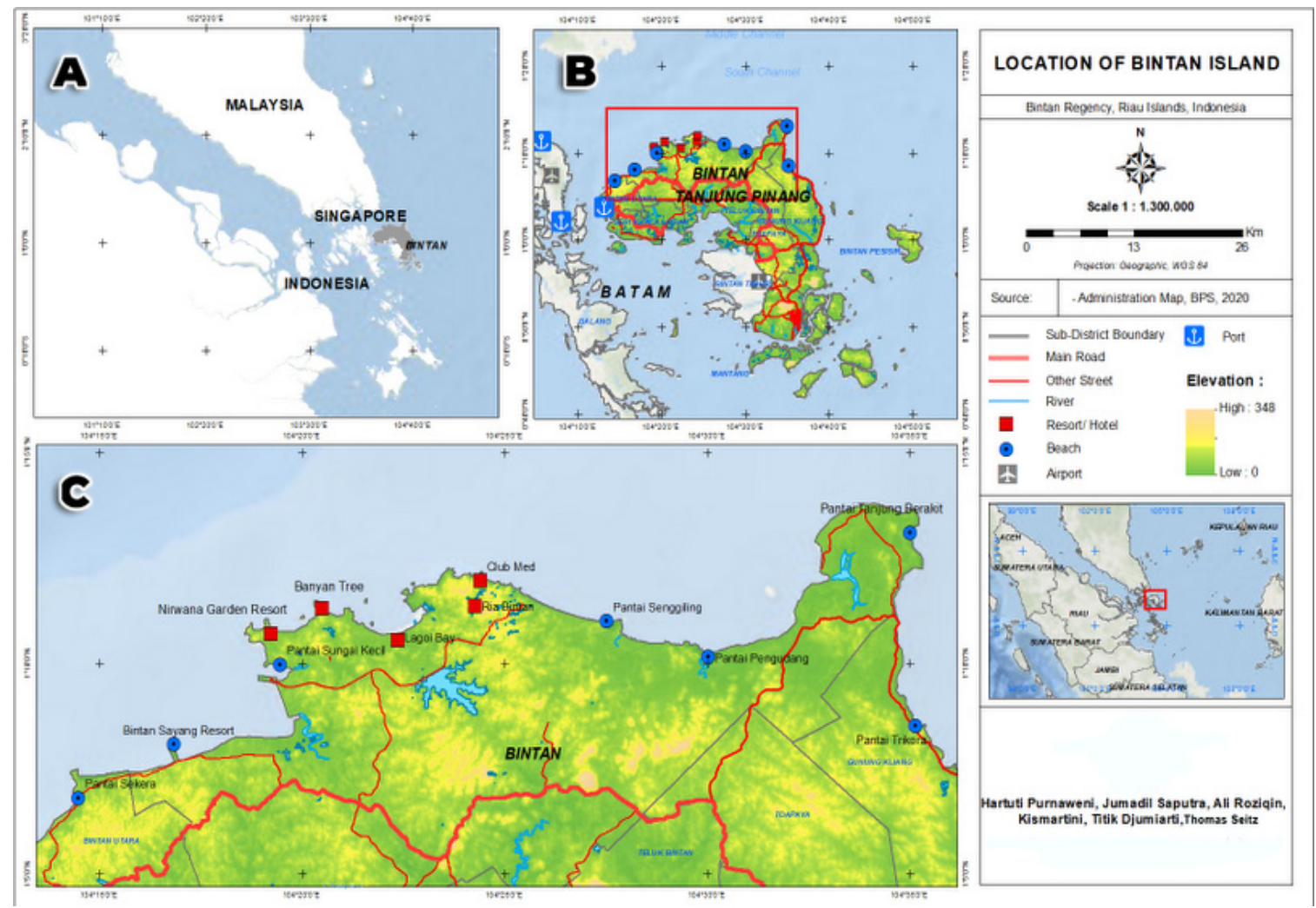

Figure 1. Location of Bintan Island.

Oil spills harm the environment [3], especially the aquatic region, due to the low level of oil biodegradation [12]. In addition, pollution caused by this natural substance can harm the socio-economic community [31] by decreasing fishery production [32]. It is also detrimental to the tourism sector because Bintan is among the most popular tourist destinations amongst foreigners in Indonesia, contributing significantly to the Original Local Government Revenue [33].

Several studies have been conducted on the tourism potential of Bintan Island [25,34]. However, studies on oil spills in this region are still limited, especially on governance and policy. The research conducted by Akbar et al. [35] regarding community preparedness in oil spill governance did not provide a comprehensive analysis of oil spill governance. The study stated that communities agreed on a security/military strategy to deal with an oil spill in the Bintan Island areas. Therefore, a discussion on oil spill governance with a policy approach should be carried out for the sake of environmental sustainability.

Internationally, oil spills have been widely published in various studies. Ishak et al. [36] reported the preparedness aspect for handling oil spills in Perak, Malaysia. Olawuyi [37], Elsayed, and Ammar [11] promoted legal principles in Nigeria and Mexico, which is helpful for preventive action and the resolution of oil spill problems [12]. Meanwhile, Spezio [38] explained the freedom of federal states to formulate environmental policies on oil spills in the United States.

Solo-Gabriele et al. [39] suggested using an integrative approach from various scientific fields to overcome oil spills in the future. This approach is especially important because many ships pass through the Strait of Singapore to Malacca, an important world trade route. In the public administration and environmental management approach, Elsayed and Ammar [11] stated the need for a review related to sustainability governance, indicating multi-stakeholder collaboration in overcoming oil spills. This governance approach can be used to analyze the oil spill case in Bintan.

Based on previous studies regarding oil spills and study locus, discussions of policy management, and strategies, the right handling processes are still limited. Therefore, 
this study aims to analyze the condition of the oil spill in Bintan Island and provide a recommended strategy for stakeholders concerning the right governance and policy.

\section{Study Area}

Bintan Island is part of the Riau Islands Province, located between the Malacca Strait and the Karimata Strait. Figure 1 shows that Bintan sea waters are directly adjacent to Singapore and Malaysia. Bintan is the largest island in the Riau Islands Province, which in its entirety consists of 3000 large and small islands. Bintan is the center of three levels of government, namely the Riau Islands Province Government, which is in Dompak Island, Tanjungpinang City Government (Senggarang, Johor, Malaysia), and the Bintan Regency Government (Bandar Seri Bintan, Riau Islands, Indonesia).

Figure 1, panel A shows that Bintan sea waters are directly adjacent to Singapore and Malaysia. Meanwhile, panel B visualizes the Island, where the red box indicates the potential oil spill cases zoomed-in panel $\mathrm{C}$. The territorial waters of this Island are the point that connects the Malacca strait with oil trade routes originating from the Middle East and Asian industrial countries, such as China, Taiwan, South Korea, and Japan. Strategic sea lanes are used by many ships carrying out various marine activities, such as tank cleaning. They are prone to oil spills due to accidents $[1,35,40]$, which can damage the marine ecosystems in the Bintan Islands [35].

Additionally, to the diverse marine ecosystems, the waters of the Bintan Island have various beautiful tourist destinations such as Lagoi Beach, Nirwana Garden Resort, Banyan Tree, The Sanchaya, The Lagoi Bay, and Turi Beach Resort. Many international tourists, especially from Malaysia and Singapore, have made Bintan Island a popular tourist destination, as evidenced by the number of foreign visits, which reached 265,904 in June 2019. However, international tourist visits continue to decline because most areas are polluted by oil spills, especially during the north wind season from November to February. Tourism in Bintan, which significantly contributed to the tourism sector in the Riau Island Province, is also affected [33].

In early 2020, the number of foreign tourists reached 192,856, which indicates a decrease compared with 2019 due to the increasing cases of oil spills [41,42] caused by the COVID-19 pandemic [43,44]. Tourism on Bintan Island relies heavily on healthy coastal ecosystems and clean seas. In other Indonesian regions, such as Kepulauan Seribu, cases of oil spills have disrupted tourism activities [7]. Therefore, adequate cleaning, which costs approximately 300,000 USD/ton on the high seas and 29,000 USD/ton on the coastal areas, is needed. This cost is certainly very burdensome for local governments, making tourism business owners, such as hotels and resorts, uncertain of their income. According to Suryanti [45], approximately IDR 2,354,073,167, or USD 150,000, was cumulatively lost at the five resorts on the Islands due to cleaning and monitoring fees, as well as room cancellations.

Oil spills in Bintan are reported to have occurred since the 1970s and have increased in the last five years [41,42]. According to Riberio et al. [46], its leads to an adverse impact on areas dependent on the tourism sector. Based on the interviews and local government report, oil spill in the Bintan Island was detected in several northern coastal areas, such as Sebong Pereh, Sakera Lagoi Tourism Area, Berakit, and Pengudang Villages. Figure 2 shows oil spill areas, which are represented with blue squares. 


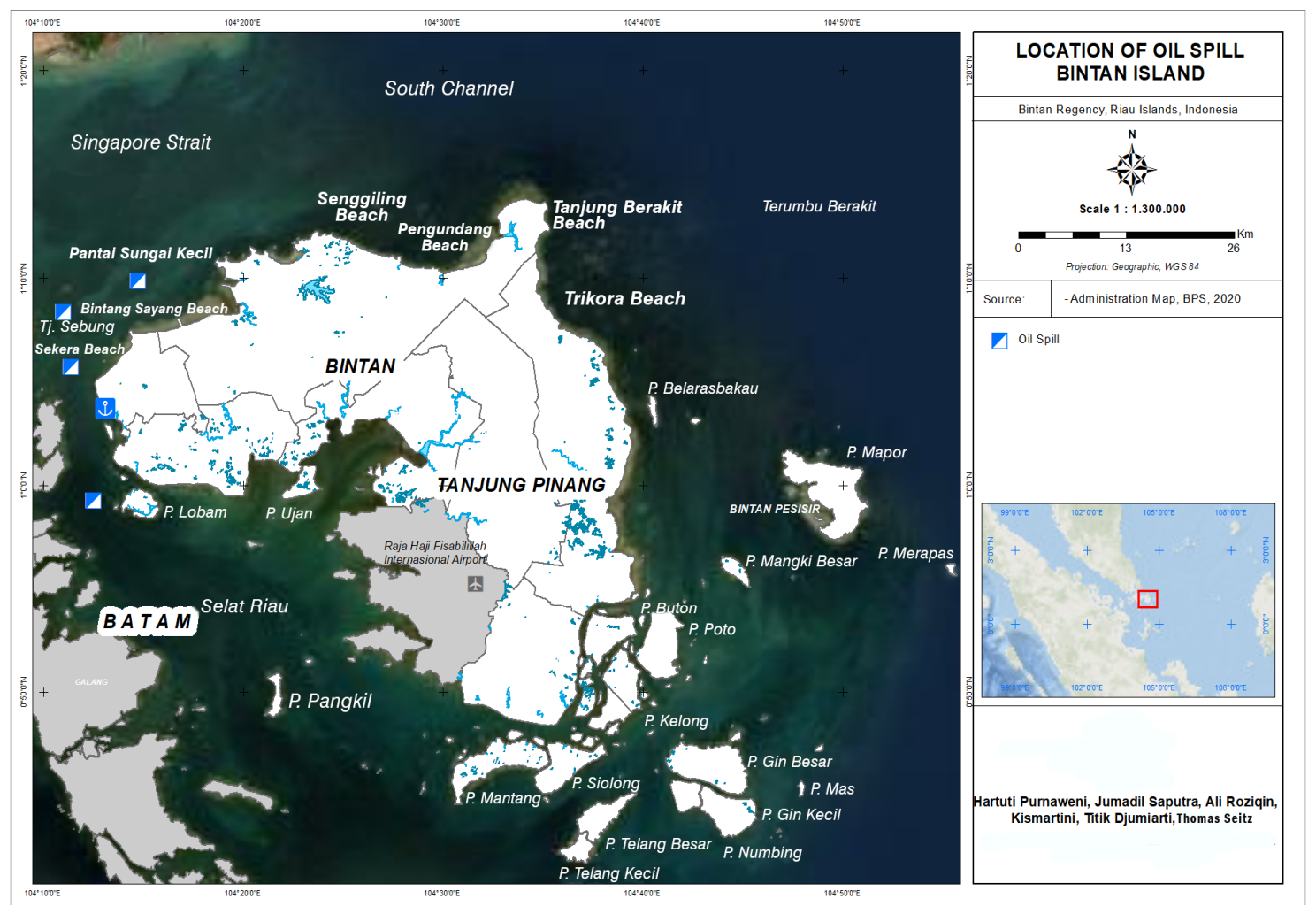

Figure 2. Distribution information of oil spill in Batam-Bintan waters.

Based on Figure 2, four coastal locations often experience the impact of oil spills, namely Sungai Kecil beach, Bintang Sayang beach, Sakera beach, and the coastal area of Lobam Island. Additionally, complaints from communities to the Bintan Regency government include those from Sebong Lagoi, Sebong Pereh, Bintan Utara, Malang Rapat, Berakit, Sri Bintan, and Pengudang.

\section{Oil Spill Governance}

Apart from positively impacting a country, this industry poses a high risk to environmental sustainability through spills at seas [9]. As part of a profit organization, the oil industry requires a systematic authority mechanism in case of an accident. The legitimacy of corporations demands social responsibility (CSR) and agility to solve social problems [11]. However, for the oil industry, ignoring this responsibility can negatively affect society and the environment, making the oil spill problem complex [8].

Since 1992, many oil spill cases have occurred in various countries around the world [9], such as the USA [14,38,47], China [48], Nigeria [37,49], Brazil [10], Mexico [1,11], Malaysia [2,50], Philippines [51], and Singapore [19,52]. In many cases of oil spills, a rapid response is required for effective handling to minimize loss. It also implies the need for national, regional, and international policies to provide compensation rights for the injured party, given that the impact of oil is usually long-term [37,53]. Therefore, communication between the government, private industry, volunteers, and local communities is vital in overcoming oil spill cases $[31,54]$.

When responding to oil spills, a clear responsibility is required among stakeholders [14] related to compensation. Several international conventions address compensation from oil spills, such as the International Convention on Civil Liability for Oil Pollution Damage (CLC) Fund Compensation (FC) conducted in 1992. A total of 135 countries have ratified the 1992 CLC, which has 114 members as of December 2016 [9]. Furthermore, comprehensive policies are required to minimize risks to human health, socio-economic losses, and environmental damage. The policy should consist of preventive, prepared, and 
responsive measures in case of oil spill [12] as well as strategies to manage disasters from all parties.

In the framework of public administration, the state or government plays an essential role in overcoming oil spill-related problems [55], both as regulators and service providers. Government must utilize all available sources along with stakeholders [56]. According to Willmes and van Wessel [56], the network governance framework has three critical points, namely identifying stakeholders, determining their contribution, and government norms. Public confidence is affected by the government's responsibility to overcome the problem of oil spills [57] because most people suffer a lot of losses, especially fishers and those that depend on coastal areas to survive.

Oil spill governance contains strategic elements of policies carried out by the government, oil industries, and civil society. One of these strategies is the development goals that led to a world agreement known as the sustainable oil industry. According to Olawuyi [37], the following three considerations must be balanced to achieve a sustainable oil industry.

\subsection{Economic Criteria}

The existence of the oil industry needs to be beneficial to local entities, provide the balance of payments and technology transfer. The state must also be committed to developing clean and efficient technologies.

\subsection{Social Criteria}

Countries with the oil industry must distribute their resources evenly through the proper regulation of social responsibility and profits earned from oil exploration. An example is providing social, educational, and health facilities to local communities affected by the company's operations.

\subsection{Environmental Criteria}

This is the most crucial principle, which aims to ensure the needs of today's population do not sacrifice those of future generations. The Rio Declaration reinforced the development and the environment that humans need to protect for the present and future.

The following chart (Figure 3) is a framework analysis of oil spillage governance.

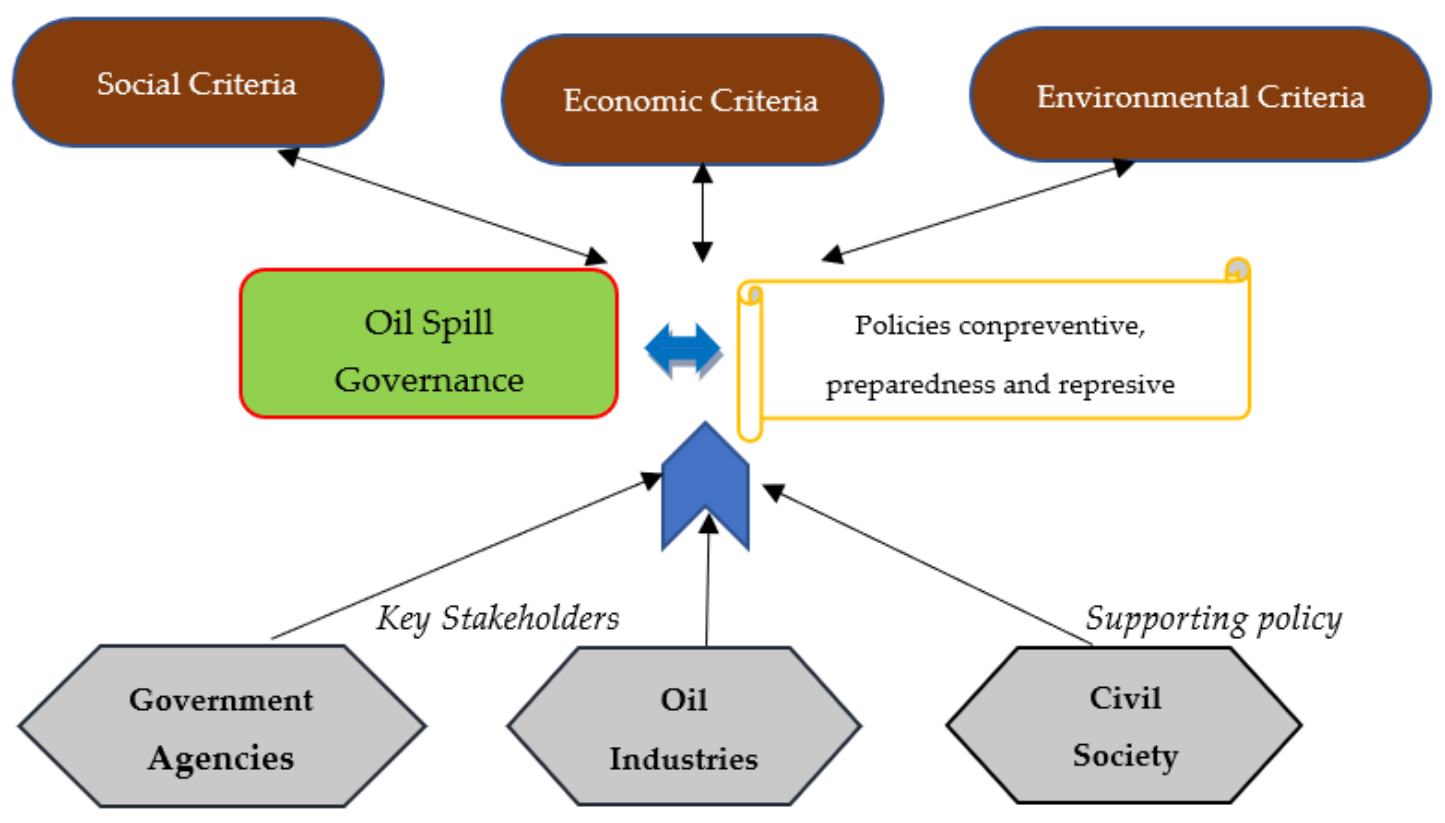

Figure 3. Framework analysis of oil spill governance.

Figure 3 shows that the government and the oil industries are the critical parties in handling spills. Civil society's responsibility is only passive due to low authority. However, 
it can be formed by advocating the government, assuming no compensation is given to those affected. In overcoming cases of oil spills, stakeholders face many challenges, including both natural and non-natural factors. Examples of natural factors include sea conditions, wind speed, direction, ocean currents, and tides. Non-natural factors emphasize the equipment and technology used for clean-up.

\section{Methods}

This research is qualitative with a case study approach. According to Bennett et al. [58], case studies are methods that comprehensively analyze various data sources to provide information on complex research phenomena in real-life contexts. This method was selected to help analyze practical problems, namely, the oil spill on Bintan Island. Meanwhile, case studies help to ensure the authors are immersed in the context and obtain an in-depth understanding of the phenomenon [59]. The case study approach also aims to answer "how" and "why" questions regarding oil spill governance. In providing answers, the case of oil spills in Bintan was narratively analyzed, and the methods needed to develop governance strategies to deal with oil spills were considered.

Data were collected through semi-structured interviews and Focus Group Discussion (FGD) with government officials at the national, province, regency, and village levels. This is in addition to the tourism sector, such as hotels, restaurants and food stalls, fishermen, local people, and preliminary studies. Furthermore, direct nonparticipant observations to several water points on Bintan Island were performed to determine the actual conditions in the field. To ensure the quality and rigor of academic research, the data collected were validated with several secondary documents such as regulations, official government reports, factual news, and related previous studies. Finally, the data are explained exploratively to answer the questions. Figure 4 shows a detailed pictorial representation of the research flow.
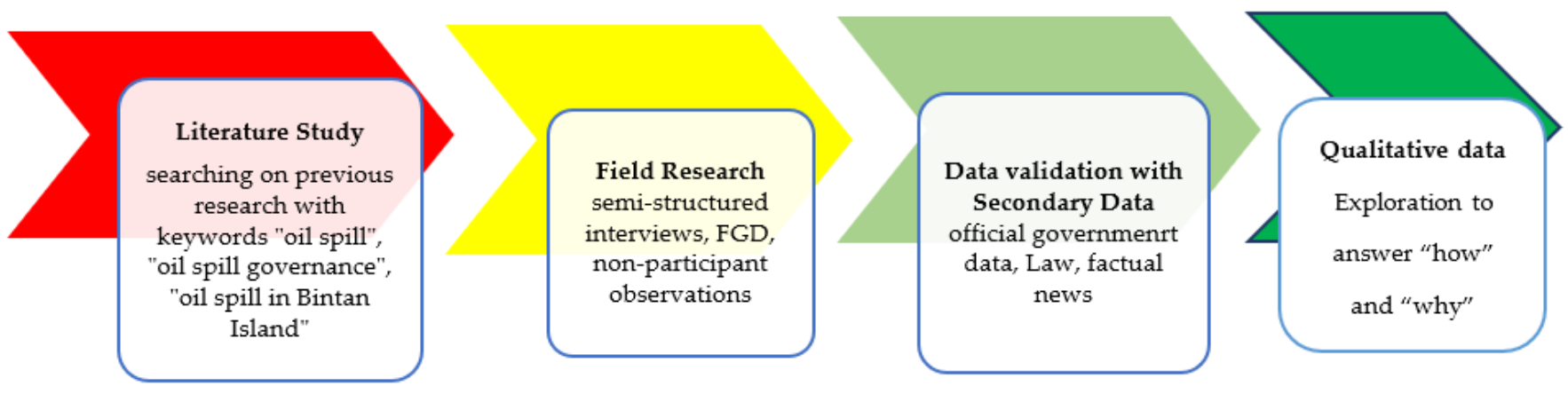

Figure 4. Research process.

\section{Results and Discussion}

\subsection{Oil Spill and Its Impact in Bintan Island}

Cases of oil spills often occur in various countries, thereby leading to polluted sea conditions and socio-economic losses [49,50,60], similar in Riau Islands Province, Indonesia. Almost every year, cases of oil spills occur in this region [61], with the worst hit for the last five years being Bintan Island [42]. Therefore, based on the FGD results, the local government is encouraged to deal quickly with oil spill cases. According to Sulma et al. [42], the type of oil that pollutes the northern coastal waters of Bintan Island strongly indicates that the lumps of dirty oil are obtained from the illegal cleaning of tanks for ships sailing in the waters of the South China Sea. Pollution due to oil spills in the sea is also experienced by neighboring countries, such as Malaysia [2,50], Singapore [19,52], and the Philippines [51]. Presently, the waters in the Riau Islands are still not safe from the threat of waste oil pollution because it is a phenomenon that has happened only once but simultaneously for decades. Therefore, Bintan Island needs to be continuously cleaned of oil spill waste [41].

Approximately 76 tons of waste due to oil spills was recorded from 2017 to 2020 [62]. Throughout 2020, oil spills collected in the Lagoi coastal area reached 299 drums, which 
increased significantly from 73 drums obtained in 2019 [63]. According to Puspitasari [40], the spread of oil spills in Bintan waters occurs every two to five days, with the extent in the sea waters influenced by wind and tides. Puspitasari [40] also reported a total of 1767 barrels of oil spills, with 1157 polluting the coast, 600 evaporated, and four in unknown conditions. Furthermore, 20 areas have been predicted to be affected by the oil spill on Bintan Island based on the Environmental Sensitivity Index (ESI).

Figure 5 shows oil spills on the coast of Bintan Island with panels A, B, and C indicating lumps of oil sludge lumps widely on the beach and polluted sea waters with a deep black color. The case of oil spills is a security issue that poses three significant threats to residents in coastal areas [1,64], which covers Environmental, Human, and Socio-economic Securities, adopted from Olawuyi [37].

A

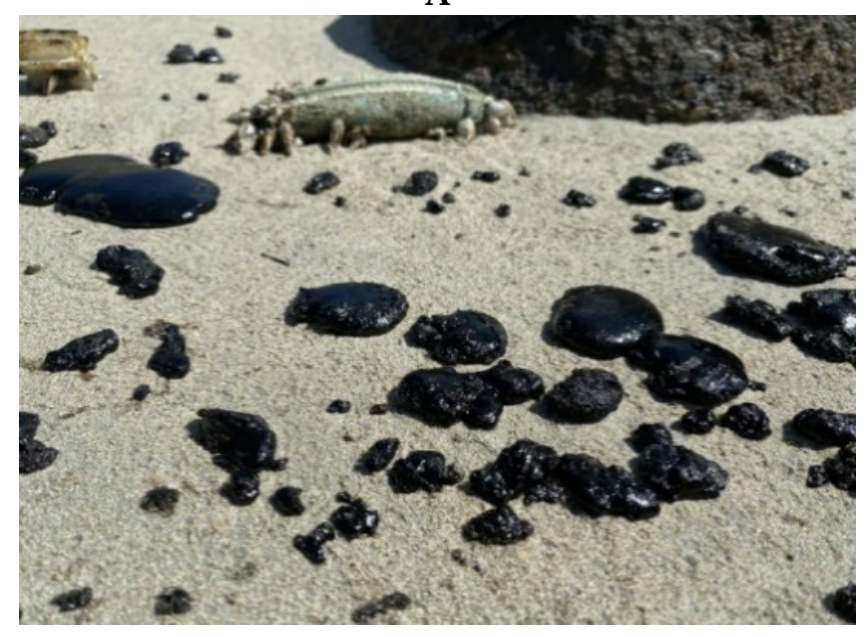

B

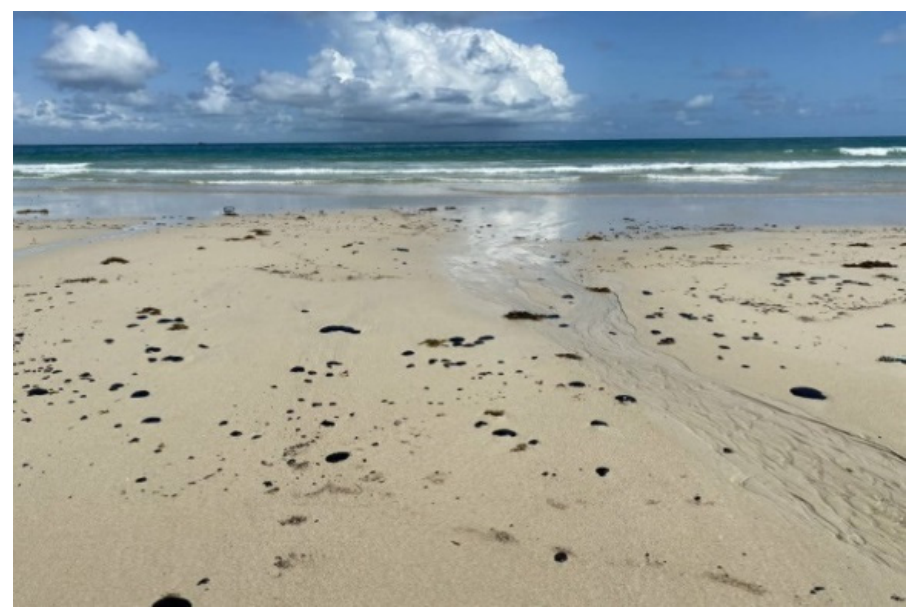

C

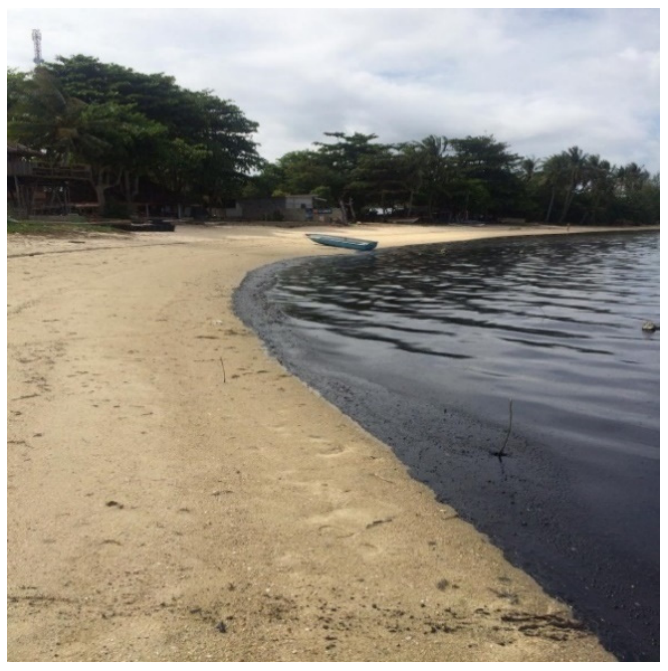

Figure 5. Evidence of an oil spill on the coast of Bintan Island.

The environmental security threat has been felt by coastal communities in the northern region of Bintan Island, as shown in Figure 5. The expanse of waste from the oil spill in Bintan has disturbed the balance of marine life, even reaching the shores of this Island. This has unsettled the fishermen because the oil spill pollution led to a decrease in fishing, thereby disrupting community welfare in Bintan [35].

Oil spills caused environmental damage to marine and coastal biota along the North Coast of Bintan Island due to its large wealth of natural resources, such as seagrass beds with an abundant diversity of marine biota [65]. Subsequently, seagrass beds play an essential role for several endangered biotas, such as dugongs, which use them as their 
primary source of food [66]. Threats to human security are in the form of health hazards, which concern seawater pollution. According to FGD, Fish contaminated with oil spills and consumed by humans can affect public health.

The third security impact is the significant economic threat that needs to be addressed [67]. Oil spill waste pollution is very disturbing for local and international tourists because the black mud puddle inundates the beach sand on several coastlines, spoiling vacation spots [67]. Tourists and hotel managers in the Lagoi area stated that they are disturbed by the appearance of black oil in the form of small lumps and are reluctant to play or bathe on the beach. This condition is disadvantageous for resort owners and other tourism actors.

In addition to the three security threats, the long-term and short-term impacts caused by oil spills need to be considered. The short-term ecological impact is that hydrocarbon molecules can damage the cell membranes of marine biota, thereby leading to the release of cell fluid and the penetration of these materials into the cells [39]. Oil can also cause direct death to fish due to lack of oxygen, carbon dioxide poisoning, and exposure to other dangerous chemicals [32]. The long-term consequences are more threatening to marine habitats, which consume food affected by some oil compounds. Its impact on the oil accumulation in the zooplankton moves to the predatory fish when eaten by larger marine animals and even humans [40].

The pollution caused by oil spills that inundate the oceans with their complex structure can destroy marine wealth and disrupt the fertility of the mud on the seabed. Fishes within this vicinity either die or migrate to other places. The coral reefs and mangroves also feel as much as $50 \%$ fatally damaged due to these marine biotas, thereby affecting fishing activities [66]. The following excerpt is from an interview with a local fisherman in Bintan Island:

"This oil spill has affected my fish catch. In some months, I cannot even go to the sea due to the severe spillage level and death of numerous fish."

The Department of Maritime Affairs and Fisheries (DKP) stated that dugongs living in the Riau Islands are decreasing due to marine pollution on the Malacca peninsula [32]. According to the CTI-LIPI Core map, several marine biotas in the waters of the Bintan Regency, such as dolphins, sharks, whales, sea horses, clams, Lola, sea cucumbers, and Napoleon fish, need to be protected because they are threatened with extinction. In addition, other sea inhabitants, such as green (Chelonia mydas), Hawksbill (Eretmochelys imbricata), and Lekang (Lepidochelysolivacae) turtles which uses dugong and seagrass conservation as homes [66], also experience a population decline [68].

Cases of waste oil spills that often occur in Bintan have damaged coastal areas, such as coral reef ecosystems, seagrasses, and mangrove forests [69]. Damage to ecosystems due to spilled waste oil can cause the death of marine organisms, such as coral, reef fish, algae, and seagrass, break the sea's food chain, and decrease the primary water productivity. Finally, it is economically detrimental because it disrupts people's livelihoods depend on marine waters [70].

Many threats associated with oil spills are the responsibility of the Provincial and the Central governments [64]. Therefore, as the leading actor in the international system, the state needs to translate the potential threat as a nontraditional security aspect capable of disrupting Indonesia's domestic security [64]. The regional and central governments have attempted several substantial efforts to respond to the Bintan spill case, which refers to a constructivist approach to formulate regulations for hazardous oil spill waste pollution through domestic legal products [71].

The categorization of hazardous waste based on Government Regulation No. 101 on Management of Hazardous and Toxic Waste explains that the level of danger from chemical and industrial wastes focuses on human safety aspects and environmental balance [40]. Pollution due to the oil spill in Bintan has also clearly threatened the marine life environment, therefore, law enforcement must be implemented. Although international values and norms were adopted to formulate Government Regulation No. 101 in legal principles, 
matters regulated by the government are only within the scope and capacity of domestic law [53].

\subsection{Policy Strategy on Oil Spill Governance}

Oil spills in several regions worldwide triggered national, regional, and international policies [37], which aim to prevent, control, and provide compensation to the impacted community and the environment. Cases of waste pollution due to oil spills in Bintan often occur in international sea areas, indicating that Indonesia's positive domestic law cannot be prosecuted. The perpetrators of environmental pollution, particularly oil spills, are alleged to be foreign ships that dump waste in international seas [10].

According to two interviewed staff of Marine Research Centre, the National Ministry of Maritime Affairs and Fisheries, ships entering Singapore waters must have clean tanks or pay to have them cleaned at facilities in Singapore. Therefore, some tankers prefer cleaning their tanks before entering Singapore, as stated by the informant from the marine research center. A ship crew stated that the ship tanks are usually cleaned in the international waters area, which flows from Singapore Strait to the east or south direction, from November to March during sea waves. A lecturer at Palembang River, Lake and Crossing Transportation Polytechnic, as well as a former international ship's machinery crew, stated that the violating ships' or tankers' operators tend to calculate the hydrodynamic of the sea waves. Therefore, the oil sludge is unlikely to enter Singaporean waters with strict regulations.

This means that sanctions for acts of environmental pollution will only ensnare the perpetrators that directly dispose of wastes in the Indonesian territory. The waves and ocean currents carry the wastes to the exclusive economic zone or even mainland Indonesia, thereby polluting the waters of Bintan Island. This condition makes it difficult for the Indonesian government to enforce laws capable of bringing the perpetrators to book. Table 2 displays some government policies and regulations related to handling oil spill cases in Indonesia.

Table 2. Government policies related to oil spill handling.

\begin{tabular}{|c|c|c|}
\hline No & Government Policies & Summary in Oil Spill Governance \\
\hline 1 & $\begin{array}{c}\text { Law number } 32 \text { of } 2009 \text { on } \\
\text { Environmental Protection and } \\
\text { Management }\end{array}$ & $\begin{array}{l}\text { Anyone that causes environmental } \\
\text { pollution and/or destruction is } \\
\text { responsible for cleaning up the mess and } \\
\text { restoring the environment's functioning. }\end{array}$ \\
\hline 2 & $\begin{array}{c}\text { Presidential Regulation Number } 109 \text { of } \\
2006 \text { on Mitigation of Oil Spill Emergency } \\
\text { Situations at Sea }\end{array}$ & $\begin{array}{l}\text { Every company/unit/person is } \\
\text { responsible for dealing with an } \\
\text { emergency oil leak in the sea resulting } \\
\text { from their business and/or activities. }\end{array}$ \\
\hline 3 & $\begin{array}{c}\text { Law Number } 27 \text { of } 2007 \text { on the } \\
\text { Management of Coastal Areas and Small } \\
\text { Islands }\end{array}$ & \\
\hline 4 & $\begin{array}{c}\text { The Minister of Environment Regulation } \\
\text { Number } 7 \text { of } 2014 \text { on Environmental } \\
\text { Losses Due to Pollution and } \\
\text { Environmental Damage }\end{array}$ & $\begin{array}{l}\text { Determining and calculating } \\
\text { environmental losses. }\end{array}$ \\
\hline 5 & $\begin{array}{c}\text { Decree of the Minister of Marine Affairs } \\
\text { and Fisheries Number: } \\
54 / \text { KEPMEN-KP / } 2016\end{array}$ & $\begin{array}{l}\text { Creating national and local team to } \\
\text { handle oil spill cases. }\end{array}$ \\
\hline 6 & $\begin{array}{l}\text { The Minister of Transportation } \\
\text { Regulation Number } 58 \text { of } 2013 \text { on the } \\
\text { prevention of pollution in the waters and } \\
\text { ports }\end{array}$ & $\begin{array}{l}\text { Every company must have oil storage } \\
\text { facilities in the waters and port activities } \\
\text { must satisfy the pollution prevention } \\
\text { requirements, namely, the procedure } \\
\text { personnel, and equipment. }\end{array}$ \\
\hline
\end{tabular}


Table 2. Cont.

\begin{tabular}{ccc}
\hline No & Government Policies & Summary in Oil Spill Governance \\
\hline 7 & $\begin{array}{r}\text { Decree of the Governor of the Riau } \\
\text { Islands Number 742 of } 2018\end{array}$ & $\begin{array}{c}\text { Creating a local team to handle oil spill in } \\
\text { the Riau Province. }\end{array}$ \\
8 & $\begin{array}{r}\text { Decree of the Minister of Transportation } \\
\text { Number 263 of 2020 }\end{array}$ & $\begin{array}{c}\text { Budgeting costs to handling oil spill } \\
\text { under local government authority. }\end{array}$ \\
\hline
\end{tabular}

Base on the Table 2, oil spills that pollute the environment at a macro level have been regulated in Law number 32 of 2009 on Environmental Protection and Management. Furthermore, the handling of related cases is covered through Presidential Regulation No. 109 of 2006 on Mitigation of Oil Spill Emergency Situations at Sea [62]. One of the essential points in the regulation is the provision of directives to the local government in establishing a Regional Team for Mitigation of Oil Spill Emergency at Sea. This was established in 2018 and coordinates with the National Team consisting of 13 government agencies [62] in the event of an oil spill case [72].

The Central Government should not only work alone rather it needs to also collaborate with Malaysia and Singapore to manage oil spill cases, such as to facilitate the provision of data related to passing ships to determine the pollutant source [72]. Several regulations at ministerial level strengthen the government's policies on oil spill, namely, the Minister of Environment Regulation Number 7 of 2014 on Environmental Losses Due to Pollution and Environmental Damage, Decree of the Minister of Marine Affairs and Fisheries Number: 54/KEPMEN-KP / 2016 on Mitigating Oil Spill Impacts on Marine and Fishery Resources and the Minister of Transportation Regulation Number 58 of 2013 on the prevention of pollution in the waters and ports.

The Provincial Government of Riau Islands implemented Law No. 1/2014, an amendment of Law No. 27/2007 on Coastal Management and Small Islands. The law stated that the management of coastal areas and small islands aim to realize sustainable resource management and improve the welfare of the people living in the surrounding areas [47]. For this purpose, the Riau Islands Provincial Government developed a Zoning Plan for Coastal and Small Islands Management Areas (RZWP3K) in September 2018. However, the Riau Maritime Affairs and Fisheries Service (DKP) is still waiting for suggestions and opinions from the Ministry of Maritime Affairs and Fisheries (KKP). This condition doubled the delay in establishing the Regional Team, which was only erected in 2018, 12 years after the central government's authorization.

Consequently, oil spill cases are not handled appropriately due to the long absence of the authorized team and policy. Therefore, the provincial fishery and marine affairs office were set up to individually handle oil spill as shown in Table 3.

Table 3. Policy of the Provincial Fishery and Marine Affairs in Oil Spill Handling.

\begin{tabular}{ccccc}
\hline Handling the Impact & \multicolumn{3}{c}{ Year } \\
of Oil Spills & $\mathbf{2 0 1 8}$ & $\mathbf{2 0 1 9}$ & $\mathbf{2 0 2 0}$ & $\mathbf{2 0 2 1}$ \\
\cline { 2 - 5 } & 200 drum & 150 drum & 100 drum & 500 pcs \\
Preparation of drum packaging & - & - & 100 pcs & 157 drum \\
$\begin{array}{c}\text { Provision of plastic burlap sacks } \\
\text { Transportation and disposal of oil } \\
\text { spill waste through hazardous } \\
\text { waste transporters }\end{array}$ & - & - & (40 ton)
\end{tabular}

The provincial fishery and marine office handle the oil sludge by preparing drums and burlap sacks, which are used to clean the beach before sending them to Batam island's hazardous waste treatment facility. Presently, the Bintan Regency government, through Bintan Environmental Office, has organized efforts to manage the sludge oil, which is limited to beach cleaning, collecting the sludge into drums, and sending them to the Riau 
Provincial Environmental Office and the hazardous waste treatment in Batam Island for treatment [1]. The Bintan Environmental Office helps hotels and resorts by giving drums, with the budget entirely provided by private tourism sectors for hiring people in charge of beach cleaning.

Interviews conducted on village staff, local people, and owners of the restaurants and food stalls along the beach indicated that they usually clean the beach in front of their selling area without government support. They conduct the process by placing the sludge oil into sacks and burying them in the beach sand. The sludge is then hidden, which affects the beach ecosystem's sustainability.

Fishermen suffering from the sludge oil's negative impact usually feel helpless since their nets, and other fishing gears, are damaged due to oil sludge. An interviewed fisherman stated that "During the oil sludge season, the government does not pay attention to them". Furthermore, effort to solve this yearly problem is extended except a small amount of fishing gear replacement given to some fishermen. The majority of the fishermen only operate small ships; therefore, they do not go fishing during the yearly sea pollution period due to their inability to go further into the clean sea waters. There is no choice for them except to change jobs into construction laborers, builders, or some other odd jobs, waiting for the coastal waters to be cleaned.

Bintan regency government's efforts are limited to the decrease in oil impact. Therefore, the result is minimal, with an annual sludge problem since the 1970s. Meanwhile, the Provincial team founded in 2018 has not played any significant role, except data collection, limited countermeasure, and reporting of incidents to the central government. According to the Decree by the Minister of Transportation Number 263 of 2020 on Oil Spill (Tier 3) Emergency Management Procedures at Sea, oil sludge prevention and handling are under the authority of the provincial and national government. However, the allocated fund is minimal.

Data from the Hazardous Waste Section of the Riau Province's Environmental Office presented the allocated oil sludge handling budget as shown in Table 4 . This shows that several programs are funded by the provincial government, which are focused on monitoring and controlling the oil sludge, with a limited budget. Presently, no fund has been allocated for oil sludge prevention.

Table 4. Budget of oil spill handling in Bintan 2018-2021.

\begin{tabular}{ccc}
\hline Program & Total Items & Budget \\
\hline Purchase of drums & 200 & $\operatorname{Rp~60,000,000}$ \\
Purchase of sacks & 4350 & $\operatorname{Rp~8,700,000}$ \\
Oil sludge hazardous waste handling (drums) & 130 & $\operatorname{Rp~78,000,000}$ \\
Waste monitoring and control program for & 1 & $\operatorname{Rp~85,000,000}$ \\
environmental pollution and damage & & $\begin{array}{c}\text { Rp. 525,004,000 } \\
\text { Total }\end{array}$ \\
\end{tabular}

Source: Environmental Agency of Riau Islands Province [74].

Activities by the regency and provincial government show their limited efforts, which indicates a weak governance system on oil sludge management. Meanwhile, the Bintan Regency Government has issued several domestic policies as the lowest policymaker level [72], mostly in oil sludge handling. Conventional and manual methods still clean the restoration of areas contaminated with sludge oil by collecting the oil into drums. The local government has limited authority in dealing with this problem because it involves international waters bordering Indonesia, Malaysia, and Singapore. Therefore, the responsibility must be performed by the central government.

One of the strategies for disposing of oil spills is collecting them using chemicals $[3,75]$. However, this method is expensive and not environmentally friendly because they contain toxins capable of causing new problems [76]. Bioremediation technology tackles oil waste 
in the sea and coast by restoring areas polluted by sludge oil can also be carried out through bioremediation technology. Bioremediation is used to repair damaged environmental conditions using a biological approach through environmentally friendly microorganisms selected to decompose waste oil [77]. Its application is in the form of a solution sprayed onto waste oil for complete decomposition [77]. Technically, marine oil wastes can be removed through bioremediation without the availability of regulation. The use of science and technology is important alongside collaboration among ministries, institutions, and multi-instrumental law enforcement [78].

Indonesia has a significant commitment to protecting and governing natural resources sustainably, as stated in Law Number 27 of 2007 concerning the Management of Coastal Areas and Small Islands [61]. This is in accordance with the 2005-2025 National Long-Term Development Plan titled, "The future direction of development needs to pay attention to the utilization and supervision of a vast marine area". It was conducted with an extensive scope, prospect of marine resources and through a multisectoral, integrative, and comprehensive approach to minimize conflict and maintain its sustainability [61].

Oil sludge as a hazardous waste that significantly impacts the environment has been regulated in Article 88 of Law Number 32 of 2009. Therefore, the government has the ability to enforce the law, assuming it determines the source. The Ministry of Environment and Forestry also has a plan to establish an oil waste treatment plant in Bintan [72]. According to the Director of the Maritime and Coastal Guard Unit, Ministry of Transportation, a Port State Control system is designed to check the passing ships [62].

Indonesia needs to be proactive in controlling oil spills from unknown sources by using sophisticated data, sea operations, checking ships at ports, and cooperation with related parties, including ASEAN (Association of Southeast Asian Nations) and other countries in the world [12]. Furthermore, information needs to be disseminated to ship captains and agents, who in turn submit their waste oil to licensed managers [11]. Compensation mechanisms can be urged for shipping industries by providing CSR for the disadvantaged parties, especially fishermen. The community also needs to be urged to be actively involved through advocacy activities, leading to a stronger involvement of governance actors.

However, the government policies have not optimally reduced oil spill problems due to weak coordination, such as the hierarchical structure of the bureaucracy and the involvement of many stakeholders, which affect the overlapping authorities. The Indonesian government has issued a Presidential Decree for oil sludge from ship accidents, but there is no regulation for oil spills such as those occurring in Bintan waters. According to data collected from respondents, appropriate regulation and good coordination among the government institutions consist of Ministry of Maritime Affairs and Fisheries has radar to detect oil spill through satellite; The Oil and Gas Institution (which is under Ministry of Energy and Natural Resources) has a laboratory to act as "fingerprint" detection for the suspected ship; The navy with its Sea Safety Body (Bakamla) has territorial authority; The Ministry of Transportation is in charge with sea traffic; The Ministry of Environment and Forestry has prosecution authority for those violating environment law; The Ministry of Foreign Affairs has the authority to arrange multilateral coordination among states.

Subsequently, patrol ships from the Navy, sea police, customs as well as marine and fisheries staff are considered. A "conductor", which guarantees that good governance is applied in dealing with this oil spill problem in Bintan coastal area, is also required with the Coordinating Ministry of Marine and Investment in charge of this duty. Irrespective of the difficulty in determining the violator ship, efforts need to be exerted to solve this annual problem in Bintan. The cost is enormous to the tourism industry, fishermen, and local people. The ecosystem has also suffered, thereby threatening the sustainability of the island. Therefore, better governance is badly needed in solving the oil spill problem in Bintan coastal area for good environmental governance and sustainable development.

The government plays an essential role in overcoming problems and providing good service in the public administration framework. It has the responsibility to use all relevant sources and stakeholders, and the policy must cover oil spill prevention, mitigation, and 
recovery. The government, private industry, volunteers, and local communities need to coordinate in dealing with the oil spill cases [31,54].

\section{Conclusions}

This study has succeeded in providing a recommendation of oil spill governance in a policy and governance approach by exploring the Bintan Island. This study departs from merely recording the increasing number of cases to determining the harmful social, economic, and environmental impacts. It also aims to explore the governance carried out by stakeholders to understand the strategies in tackling future oil spills on this Island. Based on the results, the government regulations in dealing with oil spills are not updated quickly enough, therefore, it is less effective. In addition, hierarchical and overlapping mechanisms between stakeholders make it difficult to coordinate effectively. Meanwhile, the government's handling pattern is still focused on repressive efforts and no preventive measures.

Therefore, this study recommends that policymakers to (i) build-up a structured coordination system from ministry level to local government through the revision of Presidential Regulation Number 109 of 2006 concerning Mitigation of Oil Spill Emergency Situations at Sea. (ii) to optimize the regional/local teams in the process of handling oil spill cases. (iii) to encourage and increase the monitoring and patrolling of oil spills through creating Port State Control Officer and (iv) to propose the environmentally friendly techniques to reduce oil spill lumps in the sea.

This study focused on efforts to overcome oil spills, emphasizing the role of governance and policy. However, other issues such as chemical elements and the level of damage to oil spills in Bintan have not been discussed. In the case of oil spills that occur yearly on Bintan Island, an in-depth mapping of the level of environmental damage is needed. Due to the low level of the policy coordination process, it is necessary to conduct further research to analyze the role of institutional stakeholders in oil spill governance policies in the region, with Artificial Intelligence (AI) used to detect the sources of unknown spills.

Author Contributions: Conceptualization, H.P.; Formal analysis, H.P., J.S., K.K. and T.S.; Funding acquisition, H.P.; Investigation, H.P.; Methodology, T.D.; Project administration, K.K. and T.D.; Supervision, H.P.; Validation, J.S. and T.S.; Writing—original draft, A.R.; Writing—review \& editing, A.R. All authors have read and agreed to the published version of the manuscript.

Funding: This research is funded by DIPA FISIP-Undip research fund, based on Keputusan Dekan FISIP Universitas Diponegoro No. 00312/UN7.5.7.2/HK/2021, on Joint Research of International Collaboration with Universitas Terengganu, Malaysia.

Data Availability Statement: Not applicable.

Acknowledgments: The authors would like to thank Universitas Diponegoro and Universiti Malaysia Terengganu for supporting this research and publication. We deeply appreciate our informants from the Ministry of Marine and Fisheries (Widodo S. Pranowo, Budhi G. Gautama), Riau Provincial Government and Bintan Government (Office of Marine and Fisheries, Office of Environment), academicians (Sutrisno Anggoro, Agus Tjahjono), the local researchers who have helped us immensely, and the local communities. We would also like to thank the reviewers for all the constructive comment.

Conflicts of Interest: The authors declare no conflict of interest.

\section{References}

1. Al-Majed, A.A.; Adebayo, A.R.; Hossain, M.E. A sustainable approach to controlling oil spills. J. Environ. Manag. 2012, 113, 213-227. [CrossRef]

2. Ishak, I.C.; Rani, W.M.H.W.A.; Ismail, S.B.; Mazlan, N. A Study of Oil Spill at Marine Companies: Factors and Effects. In Advancement in Emerging Technologies and Engineering Applications; Springer: Berlin/Heidelberg, Germany, 2020 ; pp. 1-12. ISBN 9789811500015. 
3. Torres, D.H.A.; da Costa Dias, F.; Bahiana, B.R.; Haddad, A.N.; Chinelli, C.K.; Soares, C.A.P. Oil Spill Simulation and Analysis of Its Behavior Under the Effect of Weathering and Chemical Dispersant: A Case Study of the Bacia de Campos-Brazil. Water Air. Soil Pollut. 2020, 231, 521. [CrossRef]

4. Jabbar, M.A.; Soesilo, T.E.B.; Hamzah, U.S.E. Oil Spill Incidents and Their Impacts to Fisheries and Tourism Activities in Kepulauan Seribu. E3S Web Conf. 2018, 68, 03013. [CrossRef]

5. Abimanyu, A.; Pranowo, W.S.; Faizal, I.; Afandi, N.K.; Purba, N.P. Reconstruction of Oil Spill Trajectory in the Java Sea, Indonesia Using Sar Imagery. Geogr. Environ. Sustain. 2021, 14, 177-184. [CrossRef]

6. UNCTAD. Review of Maritime Transport; United Nations Publications: New York, NY, USA, 2020.

7. Sulistyono, S. Dampak Tumpahan Minyak (Oil Spill) di Perairan Laut Pada Kegiatan Industri Migas dan Metode Penanggulangannya. Forum Teknol. 2013, 3, 49-57.

8. Assilzadeh, H.; Gao, Y. Designation of an interactive oil spill management system. Disaster Prev. Manag. Int. J. 2010, 19, $233-242$. [CrossRef]

9. Soto-Oñate, D.; Caballero, G. Oil spills, governance and institutional performance: The 1992 regime of liability and compensation for oil pollution damage. J. Clean. Prod. 2017, 166, 299-311. [CrossRef]

10. Zacharias, D.C.; Gama, C.M.; Fornaro, A. Mysterious oil spill on Brazilian coast: Analysis and estimates. Mar. Pollut. Bull. 2021, 165, 112125. [CrossRef]

11. Elsayed, N.; Ammar, S. Sustainability governance and legitimisation processes: Gulf of Mexico oil spill. Sustain. Account. Manag. Policy J. 2020, 11, 253-278. [CrossRef]

12. Shapovalova-Krout, D. International Governance of Oil Spills from Upstream Petroleum Activities in the Arctic: Response over Prevention? Int. J. Mar. Coast. Law 2019, 34, 668-697. [CrossRef]

13. Brekke, C.; Solberg, A.H.S. Oil spill detection by satellite remote sensing. Remote Sens. Environ. 2005, 95, 1-13. [CrossRef]

14. Ramseur, J.L. Oil Spills: Background and Governance Specialist in Environmental Policy; Congressional Research Service: Washington, DC, USA, 2017.

15. Yanti, B.V.I.; Mulyawan, I.; Wijaya, R.A.; Firdaus, M.; Deswati, R.H. Legal Study Related to the Application of Compensation in a Fishery Business Affected by Oil Spill Pollution in the Sea Water Area. In Proceedings of the 3rd International Conference on Law and Governance (ICLAVE 2019), Surakarta City, Indonesia, 30-31 October 2019; Atlantis Press: Amsterdam, The Netherlands, 2020; Volume 130, pp. 231-234.

16. Robertua, V.; Karyoprawiro, B.L.; Nathalia, G.; Dhena, H. Reasoning Criminal-Implikasi Limbah Hasil Operasional Kapal Terhadap Ekosistem Laut Di Selat Malaka. J. Asia Pac. Stud. 2019, 3, 193-205. [CrossRef]

17. Masdin, M. Implementasi Ketentuan-Ketentuan United Nations Convention on The Law of The Sea (UNCLOS) 1982 terhadap Perlindungan dan Pelestarian Lingkungan Laut di Indonesia. J. Ilmu Huk. Leg. Opin. 2016, 4, 1-13.

18. AP News. Oil Tanker Carrying 78 Million Gallons Abandoned After Collision. Available online: https://apnews.com/article/e9 412fd30d47716f9bce5e4926fa7e8a (accessed on 13 September 2021).

19. Kareem, A. Oil Spill as Tankers Collide off Singapore. Available online: https://gulfnews.com/today-history/october-16-1997oil-spill-as-tankers-collide-off-singapore-1.2106300 (accessed on 13 September 2021).

20. Wibowo, M. Pemodelan Sebaran Pencemaran Tumpahan Minyak di Perairan Cilacap. J. Teknol. Lingkung. 2018, 19, 191. [CrossRef]

21. Liputan6. Kapal Tongkang Tabrakan Dengan Kapal Pengangkut Beras. Available online: https://m.liputan6.com/news/read/58 027/kapal-tongkang-tabrakan-dengan-kapal-pengangkut-beras (accessed on 13 September 2021).

22. Suhery, N.; Damar, A.; Effendi, H. Indeks Kerentanan Ekosistem Terumbu Karang Terhadap Tumpahan Minyak: Kasus Pulau Pramuka Dan Pulau Belanda Di Kepulauan Seribu. J. Ilmu Teknol. Kelaut. Trop. 2017, 9, 67-90. [CrossRef]

23. Sinurat, M.E.B.; Ismanto, A.; Hariyadi, H. Analisis Pola Sebaran Tumpahan Minyak Mentah (Crude Oil) Dengan Pendekatan Model Hidrodinamika Dan Spill Analysis Di Perairan Balongan, Indramayu, Jawa Barat. J. Oceanogr. 2016, 5, $218-226$.

24. Fatimatuzzahroh, F.; Hadi, S.P.; Purnaweni, H. Does the intervention of regional authorities contribute to sustainable mangrove ecotourism? Case study on mangrove management at Karansong, West Java, Indonesia. Ecol. Quest. 2020, 31, 7-14. [CrossRef]

25. Gde Sugihamretha, I.D. A Model of Development Maritime Tourism Competitiveness in Nikoi Island, Riau Islands Province. J. Perenc. Pembang. Indones. J. Dev. Plan. 2018, 2, 320-332. [CrossRef]

26. Panjaitan, A.D.U.; Novianti, N.; Farisi, M. Polluter Pays Principle Terkait Pertanggungjawaban Corporate PTTEP Australasia Terhadap Pencemaran Minyak Di Laut Timur Indonesia. J. Int. Law 2021, 2, 189-209. [CrossRef]

27. Reuters. Staff Ship Collision Causes 33,000 Barrel Oil Spill off Singapore. Available online: https://www.reuters.com/article/ussingapore-spill-idUSKBNOKC02J20150103 (accessed on 13 September 2021).

28. Winarto, Y. 300 ton Minyak Tumpah di Perairan Malaysia. Available online: https://amp.kontan.co.id/news/300-ton-minyaktumpah-di-perairan-malaysia (accessed on 13 September 2021).

29. Ahyadi, M.Y.; Syarifudi, A.P.; Khairunnisa, A.Z.; Ximenes, J.D.; Hamdi, M.H. Analisis Dampak Oil Spill Di Teluk Balikpapan Terhadap Kehidupan Masyarakat Dalam Perspektif Hukum Dan Lingkungan. J. Bumi Lestari 2021, 21, 18-22. [CrossRef]

30. Nurdiana, T. Petani Indonesia Menang Gugatan Tumpahan Minyak Montara, Ini Detail Kasusnya. Available online: https: / / amp.kontan.co.id/news/petani-indonesia-menang-gugatan-tumpahan-minyak-montara-ini-detail-kasusnya (accessed on 13 January 2021).

31. Chun, J.; Oh, J.H.; Kim, C.K. Oil spill response policies to bridge the perception gap between the government and the public: A social big data analysis. J. Mar. Sci. Eng. 2020, 8, 335. [CrossRef] 
32. Budiman, D.; Fitria, N. Analisis Spill Oil Terhadap Volume Dan Nilai Produksi Perikanan Di Laut Provinsi Kepulauan Riau Tahun 2018. J. Jalasena 2020, 1, 99-107.

33. Kismartini, K.; Purnaweni, H.; Djumiarti, T.; Khotimah, N. A Change in Tourism Management: New Normal Era in Riau Islands Province. In Proceedings of the 5th International Conference on Indonesian Social and Political Enquiries, ICISPE 2020, Semarang, Indonesia, 9-10 October 2020; EAI (European Alliance for Innovation): Semarang, Indonesia, 2021.

34. Enggartiasto, A.; Safitri, K.A. Bintan Island Tourism Marketing Strategy by Tour De Bintan. J. Indones. Tour. Policy Stud. 2019, 4, 26-32.

35. Akbar, D.; Setiawan, A.; Prayuda, R.; Putra, A.; Aznor, A.; Yudiatmaja, W.E. Community Preparedness on Transboundary Oil Spill Governance in Bintan Island. J. Phys. Conf. Ser. 2020, 1655, 012144. [CrossRef]

36. Ishak, I.C.; Johari, A.A.; Mazlan, N.; Ismail, S.B. The correlation between management approaches towards oil spill preparedness and response: A case study in Lumut, Perak, Malaysia. AIP Conf. Proc. 2018, 2020, 020057. [CrossRef]

37. Olawuyi, D.S. Legal and sustainable development impacts of major oil spills. Cons. J. Sustain. Dev. 2012, 9, 1-15. [CrossRef]

38. Spezio, T.S. The Santa Barbara oil spill and its effect on United States environmental policy. Sustainability 2018, 10, 2750. [CrossRef]

39. Solo-Gabriele, H.M.; Fiddaman, T.; Mauritzen, C.; Ainsworth, C.; Abramson, D.M.; Berenshtein, I.; Chassignet, E.P.; Chen, S.S.; Conmy, R.N.; Court, C.D.; et al. Towards integrated modeling of the long-term impacts of oil spills. Mar. Policy 2021, $131,104554$. [CrossRef]

40. Puspitasari, T.A.; Fuad, M.A.Z.; Parwati, E. Prediksi Pola Persebaran Tumpahan Minyak Menggunakan Data Citra Satelit Sentinel-1 Di Perairan Bintan, Kepulauan Riau. J. Penginderaan Jauh Dan Pengolah. Data Citra Digit. 2020, $17,89-102$.

41. Negara, G.S. Dampak Linkungan Terhadap Pencemaran Laut Di Pesisir Utara Pulau Bintan Selama Musim Angin Utara. J. Sains Teknol. Marit. 2020, 20, 137. [CrossRef]

42. Sulma, S.; Rahmi, K.I.N.; Febrianti, N.; Sitorus, J. Oil Spill Detection using Adaptive Threshold and Texture Analysis Methode on SAR Data. Maj. Ilm. Globe 2019, 21, 45-52. [CrossRef]

43. Goffman, E. In the wake of COVID-19, is glocalization our sustainability future? Sustain. Sci. Pract. Policy 2020, 16, 48-52. [CrossRef]

44. Roziqin, A.; Mas'udi, S.Y.F.; Sihidi, I.T. An analysis of Indonesian government policies against COVID-19. Public Adm. Policy. 2021, 24, 92-107. [CrossRef]

45. Suryanti, A. Fisheries Management Area Research: The Impact of Oil Spills on the Tourism Economy in FMA 711. Available online: https: / /www.conservation-strategy.org/news/fisheries-management-area-research-impact-oil-spills-tourism-economyfma-711 (accessed on 20 October 2021).

46. Ribeiro, L.C.D.S.; De Souza, K.B.; Domingues, E.P.; Magalhães, A.S. Blue water turns black: Economic impact of oil spill on tourism and fishing in Brazilian Northeast. Curr. Issues Tour. 2021, 24, 1042-1047. [CrossRef]

47. Bostrom, A.; Walker, A.H.; Scott, T.; Pavia, R.; Leschine, T.M.; Starbird, K. Oil Spill Response Risk Judgments, Decisions, and Mental Models: Findings from Surveying U.S. Stakeholders and Coastal Residents. Hum. Ecol. Risk Assess. 2015, 21, 581-604. [CrossRef]

48. Wang, Y.; Liu, X.; Sun, Y.; Lian, H.; Tang, X. Identification of Oil Spill from Imported Crude Oils in China Using GC/IrMS. Environ. Forensics 2013, 14, 306-311. [CrossRef]

49. Egbon, O.; Mgbame, C.O. Examining the accounts of oil spills crises in Nigeria through sensegiving and defensive behaviours. Account. Audit. Account. J. 2020, 33, 2053-2076. [CrossRef]

50. Sakari, M.; Zakaria, M.P.; Mohamed, C.A.R.; Lajis, N.H.; Chandru, K.; Bahry, P.S.; Mokhtar, M.B.; Shahbazi, A. Urban vs. marine based oil pollution in the strait of Johor, Malaysia: A century record. Soil Sediment Contam. 2010, 19, 644-666. [CrossRef]

51. Yender, R.; Stanzel, K. Tanker SOLAR 1 Oil Spill, Guimaras, Philippines: Impacts and Response Challenges; Elsevier: Amsterdam, The Netherlands, 2011; ISBN 9781856179430.

52. Kiong, J.; Saparudin, K. Major Oil Spills in the Straits of Singapore. 2010. Available online: https://eresources.nlb.gov.sg/ infopedia/articles/SIP_1101_2010-09-06.html (accessed on 20 October 2021).

53. Albert, O.N.; Amaratunga, D.; Haigh, R.P. Environmental Policies within the Context of Compensation for Oil Spill Disaster Impacts: A Literature Synthesis. Procedia Eng. 2018, 212, 1179-1186. [CrossRef]

54. Cheong, S.M. Community adaptation to the hebei-spirit oil spill. Ecol. Soc. 2012, 17, 26. [CrossRef]

55. Newig, J.; Rose, M. Cumulating evidence in environmental governance, policy and planning research: Towards a research reform agenda. J. Environ. Policy Plan. 2020, 22, 667-681. [CrossRef]

56. Willmes, R.; van Wessel, M. The Construction of (Non-)Responsibility in Governance Networks. SAGE Open 2021, 11, 21582440211030620. [CrossRef]

57. Lee, Y. Government for Leaving No One Behind: Social Equity in Public Administration and Trust in Government. SAGE Open 2021, 11, 21582440211029227. [CrossRef]

58. Bennett, S.; Mohr, J.; Deal, K.H.; Hwang, J. Supervisor attachment, supervisory working alliance, and affect in social work field instruction. Res. Soc. Work Pract. 2013, 23, 199-209. [CrossRef]

59. Takahashi, A.R.W.; Araujo, L. Case study research: Opening up research opportunities. RAUSP Manag. J. 2020, 55, 100-111. [CrossRef] 
60. Rodríguez, S.; Gil, O.; De La Prieta, F.; Zato, C.; Corchado, J.M.; Vega, P.; Francisco, M. People detection and stereoscopic analysis using MAS. In Proceedings of the 2010 IEEE 14th International Conference on Intelligent Engineering Systems, Las Palmas, Spain, 5-7 May 2010; pp. 159-164.

61. Mosriula, M. Mosriula Inventory of damage to coastal and marine ecosystems in the Kepulauan Riau, Indonesia. Akuatikisle J. Akuakultur Pesisir Dan Pulau-Pulau Kecil 2019, 3, 31-39. [CrossRef]

62. Anggraeni, R. Perkuat Penanganan Pencemaran Minyak, RI Ratifikasi Konvensi OPRC. Sindonews. 2019. Available online: https: / / ekbis.sindonews.com/berita/1435147/34/perkuat-penanganan-pencemaran-minyak-ri-ratifikasi-konvensi-oprc (accessed on 19 October 2021).

63. Zuraya, N. Delapan Resor di Bintan Tercemar Limbah Minyak Hitam. Available online: https://www.republika.co.id/berita/q4 hvp5383/delapan-resort-di-bintan-tercemar-limbah-minyak-hitam (accessed on 18 October 2021).

64. Edo, C.; Tamayo-Belda, M.; Martínez-Campos, S.; Martín-Betancor, K.; González-Pleiter, M.; Pulido-Reyes, G.; García-Ruiz, C.; Zapata, F.; Leganés, F.; Fernández-Piñas, F.; et al. Occurrence and identification of microplastics along a beach in the Biosphere Reserve of Lanzarote. Mar. Pollut. Bull. 2019, 143, 220-227. [CrossRef]

65. Abubakar, S.; Subur, R.; Rina, R.; Kadir, M.A.; Sabar, M.; Darmawaty, D.; Akbar, N. Seagrass Potential as Supporting Ecotourism in Sibu Island, Subdistrict North Oba, North Maluku Province. Agrikan J. Agribisnis Perikan. 2020, 13, 147-159. [CrossRef]

66. Hernawan, U.E.; Sjafrie, N.D.; Supriyadi, I.H.; Suyarso, I.M.; Anggraini, K. Status Padang Lamun Indonesia. Pus. Penelit. Oseanografi (LIPI), Lemb. Ilmu Pengetah. Indones. 2017. Available online: http://lipi.go.id/publikasi/status-padang-lamunindonesia-2017/1063 (accessed on 13 September 2021).

67. Aminudin. Limbah Minyak Hitam Ancam Pariwisata Bintan. TribunBatam.id. 2016. Available online: https://batam.tribunnews. com/2016/04/05/limbah-minyak-hitam-ancam-pariwisata-bintan (accessed on 19 October 2021).

68. Hangzo, P.; Cook, A.D. The Rise of Iskandar Malaysia: Implications for Singapore's Marine and Coastal Environment. SSRN Electron. J. 2019. [CrossRef]

69. Abdullah, A.; Nurrachmi, I.; Nedi, S. Analysis of Oil Content Sea Water and Diatoms Abundance in Coastal Sakera Water of Bintan Regency of Riau Island Province. J. Online Mhs. Fak. Perikan. Ilmu Kelaut. Univ. Riau 2017, 4.

70. Nukapothula, S.; Wu, J.; Chen, C. Potential impact of the extensive oil spill on primary productivity in the Red Sea waters. Cont. Shelf Res. 2021, 222, 104437. [CrossRef]

71. Sebayang, T.R. Penanggulangan limbah sludge oil di Bintan dalam perspektif konstruktivisme. Int. Acad. Conf. 2017, 1-20.

72. Maritim.go.id. Cegah Tumpahan Minyak dari Kapal, Pemerintah Sosialisasikan Pengelolaan Limbah Minyak di Kepulauan Riau. Available online: https:/ / maritim.go.id/cegah-tumpahan-minyak-dari-kapal-pemerintah-sosialisasikan-pengelolaan/ (accessed on 13 September 2021).

73. Riau Islands Provincial Office of Fishery and Marine Affairs. Focus Group Discussion; Riau Islands Provincial Office of Fishery and Marine Affairs: Riau, Indonesia, 2021.

74. Environmental Agency of Riau Islands Province. Dokumen Pelaksanaan Anggaran; Environmental Agency of Riau Islands Province: Riau, Indonesia, 2021.

75. Starbird, K.; Dailey, D.; Walker, A.H.; Leschine, T.M.; Pavia, R.; Bostrom, A. Social Media, Public Participation, and the 2010 BP Deepwater Horizon Oil Spill. Hum. Ecol. Risk Assess. 2015, 21, 605-630. [CrossRef]

76. Hammouda, S.B.; Chen, Z.; An, C.; Lee, K. Recent advances in developing cellulosic sorbent materials for oil spill cleanup: A state-of-the-art review. J. Clean. Prod. 2021, 311, 127630. [CrossRef]

77. Dell'Anno, F.; Rastelli, E.; Sansone, C.; Dell'Anno, A.; Brunet, C.; Ianora, A. Bacteria, fungi and microalgae for the bioremediation of marine sediments contaminated by petroleum hydrocarbons in the omics era. Microorganisms 2021, 9, 1695. [CrossRef]

78. Meza-Padilla, R.; Enriquez, C.; Appendini, C.M. Rapid assessment tool for oil spill planning and contingencies. Mar. Pollut. Bull. 2021, 166, 112196. [CrossRef] [PubMed] 